\title{
STUDI KASUS: ADDICTIVE MEDIA SOSIAL, PEER ACCEPTENCE DAN WELL-BEING SISWA SEKOLAH DASAR
}

\author{
Alifia Cahya Wicaksani ${ }^{1}$ dan Ika Silfiana A. Khoiriyah ${ }^{2}$ \\ ${ }^{1}$ Universitas Selamat Sri, ${ }^{2}$ Universitas Ngudi Waluyo \\ Email: alifiawicaksani1@gmail.com ${ }^{1}, \underline{\text { ikasilfiana@gmail.com }}{ }^{2}$
}

\begin{tabular}{|c|}
\hline Info Artikel \\
\hline $\begin{array}{l}\text { Sejarah Artikel: } \\
\text { Diserahkan 1 Oktober } 2019 \\
\text { Direvisi } 2 \text { Desember } 2019 \\
\text { Disetujui } 20 \text { April } 2020\end{array}$ \\
\hline $\begin{array}{l}\text { Keywords: } \\
\text { addictive social media, } \\
\text { peer acceptence, } \\
\text { well-being }\end{array}$ \\
\hline
\end{tabular}

\begin{abstract}
This study aims to determine the correlation of addictive social media, peer acceptence, and well-being in elementary school students.

The method used in this research uses a mix method which is done quantitatively and qualitatively. Quantitative method is done by giving questionnaires from each variable and then carried out by statistical tests using product moment correlation analysis. For qualitative interviews were conducted with elementary school students at SDN 1 Rejosari with in-depth interviews to find the meaning obtained.

The results showed that $r 1=-0.205, r 2=0,233$ and $r 3=0.378$. In ri there is no significant relationship because $p>0.005$ but the closeness is negative -0.205 so there is no positive relationship between addictive social media with well-being, $r 2$ shows there is a positive relationship between addictive social media with peer acceptance and r3 indicates a positive relationship between peer acceptence and well-being of elementary school students. In the case of elementary school students who cause addictive because it is closely related to peer friendship so it will connect to the level of well-being.
\end{abstract}

\begin{abstract}
Abstrak
Penelitian ini bertujuan untuk mengetahui korelasi dari addictive media social, peer acceptence, dan well-being pada siswa sekolah dasar.

Metode yang digunakan dalam penelitian menggunakan mix methode yaitu dilakukan secara kuantitatif dan kualitatif. Metode kuantitatif dilakukan dengan pemberian kuisioner dari tiap variabel kemudian dilakukan dengan uji statistik menggunakan analisis korelasi product moment. Untuk kualitatif dilakukan wawancara kepada siswa sekolah dasar di SDN 1 Rejosari dengan wawancara yang mendalam sampai menemukan makna yang didapat.

Hasil penelitian menunjukan $\mathrm{r} 1=-0,205, \mathrm{r} 2=0,233$ dan $\mathrm{r} 3=0,378$. Pada ri tidak ada hubungan yang siginfikan karena $\mathrm{p}>0,005$ namun keeratannya bersifat negatif $-0,205$ sehingga tidak ada hubungan yang positif antara addictive media sosial dengan well-being, $\mathrm{r} 2$ menunjukan ada hubungan postif antara addictive media sosial dengan peer acceptence dan $\mathrm{r} 3$ menunjukan adanya hubungan positif antara peer acceptence dan well-being siswa sekolah dasar. Pada kasus siswa sekolah dasar yang menyebabkan addictive karena berhubungan erat dengan pertemanan sebaya sehingga akan menghubungkan kepada tingkat well-being.
\end{abstract}


Alifia Cahya Wicaksani dan Ika Silfiana A. Khoiriyah

STUDI KASUS: ADDICTIVE MEDIA SOSIAL, PEER ACCEPTENCE DAN WELL-BEING ...

REFLEKSI EDUKATIKA : Jurnal Ilmiah Kependidikan, Volume 10, Nomor 2, Juni 2020, hlm. 138-143

\section{PENDAHULUAN}

Pada zaman millenial ini media sosial merupakan salah satu hiburan dalam dunia maya. Populasi penggunaan media sosial mendektai sepertiga dari populasi dunia pada bulan januari 2016 (WeAreSocial, 2016). Di Indonesia jumlah pengguna media sosial terus meningkat tiap tahunnya, menurut Kominfo (2018) pada tahun 2017 ada 243,2 juta jiwa atau setara dengan 54,68 persen dari total penduduk Indonesia, setidaknya ada 30 juta anak-anak dan remaja adalah pengguna internet. Berbagai macam aplikasi dan fitur yang ditawarkan seperti facebook memiliki 1,09 milyar pengguna aktif harian (facebook, 2016), instagram memiliki 400 juta pengguna aktif bulanan dan 80 juta foto setiap hari dengan suka sebesar 3,5 milyar (instagram, 2016), snapchat, tiktok, dan lain-lain membuat banyak individu untuk menggunakan aplikasi tersebut.

Semakin pesatnya individu menggunakan media sosial merupakan salah satu bentuk penunjukan eksistensi diri, kebutuhan ataupun pengakuan akan diri individu tersebut dengan lingkungan. Penggunaan media sosial dilihat dari sisi gender yaitu sebesar $68 \%$ dalam waktu 46 menit setiap hari, dan $62 \%$ pada pengguna lakilaki dengan waktu 31 menit tiap hari (Peerin, 2015). Hal ini membuktikan bahwa wanita yang cenderung lebih banyak menggunakan sosial media dibandingkan dengan laki-laki.

Dari berbagai penelitian disiplin ilmu hampir tidak bisa mengikuti pertembuhan yang luar biasa ini. Situs media sosial memiliki kelebihan dan kekurangan, namun yang menjadi kekhawatiran adalah dampak negatif mereka pada individu terutama kecanduan dimana pengguna terlepas dari konteks mereka, gejala nyata dari kecanduan perilaku (Andressan, 2013). Individu dapat kecanduan media sosial terutama karena efek positif dari jangka pendek suasana hati (Settani, 2018).

Addictive media sosial cenderung menggunakan media sosial untuk membantu mereka mengatasi perasaan negatif berulang dan pikiran tentang masalah pribadi, baik untuk menengkan kecemasan, stres, dan untuk berurusan dengan perasaan depresif (Andreassen, 2016) dalam jangka panjang kebutuhan untuk menghabiskan dan mengakses lebih banyak waktu di media sosial diperkirakan akan mengganggu kehidupan mereka dikehidupan pribadi mereka, misalnya produktivitas akademik, kesehatan mental, penerimaan teman sebaya (Karaisko, 2010).

Penerimaan teman sebaya lebih menunjukan antara disukai atau tidak disukai diantara kalangan teman sebaya (Marry, 2003). Rice (2003) juga mengemukakan temuanya bahwa remaja dalam penerimaan teman sebaya yaitu dengan popularitas, menyesuaiakan diri, prestasi, dan menunjukan kualitas pribadi.

Dengan melihat apa yang terjadi belakangan ini dapat mengindikasikan mengapa anak-anak bisa addictive dalam media sosial? apakah dengan aktif di media sosial para anak remaja akan lebih mudah menerima perteman sebaya? kemudian akan merasakan well-being?

Asumsi peneliti bahwa semakin tinggi addictive sosial media maka akan semakin erat dalam penerimaan teman sebaya dan well-being pada anak sekolah dasar. Dari hal tersebut khususnya di Indonesia masih jarang tentang penelitian tersebut, sehingga peneliti termotivasi untuk melakukan untuk melakukan penelitian guna untuk mendapatkan temuan terbaru dari studi eksplorasri: korelasi antara addictive media sosial, peer acceptance, dan well-being khususnya pada siswa sekolah dasar. Adapun tujuan penelitian ini yaitu untuk mengetahui korelasi dari addictive media social, peer acceptence, dan well-being pada siswa sekolah dasar.

\section{METODE PENELITIAN}

Penelitian ini menggunakan pendekatan mix methode, yaitu suatu penelitian dengan menggabungkan dua bentuk pendekatan penelitian yang mengkombinasikan antara kuantitatif dan kualitatif (Creswell, 2016). Untuk penelitian kuantitatifnya menggunakan analisis korelasi. Penelitian korelasi untuk melihat hubungan antar dua gejala atau lebih dari variabel. sedangkan untuk kualitatifnya dengan studi kasus, dengan melihat fenomena dan proses wawancara terhadap subjek.

Penelitian ini dilakukan di SDN 1 Kota Semarang. Khususnya pada kelas 6 yang berjumlah 35 siswa, dan dilaksanakan pada bulan Juli sampai Agustus 2019.

Pada tahap pengambilan data secara kuantitatif siswa diberi kuisioner dengan skala Likert baik untuk variabel addictive media sosial, peer acceptence dan well-being. Sedangkan untuk secara kualitatif yaitu melalui pengamatan 
terhadap siswa dan melakukan wawancara sampai mendapatkan makna dari kasus tersebut.

Pada penelitian mix method ini langkah yang pertama yaitu menganalisis secara kuantitatif yaitu dengan pembagian kuisioner disetiap variabel baik variabel addictive media sosial, peer acceptence dan well-being dengan skala likert.

Alur penelitian ini dapat dilihat pada gambar 1 dibawah ini:

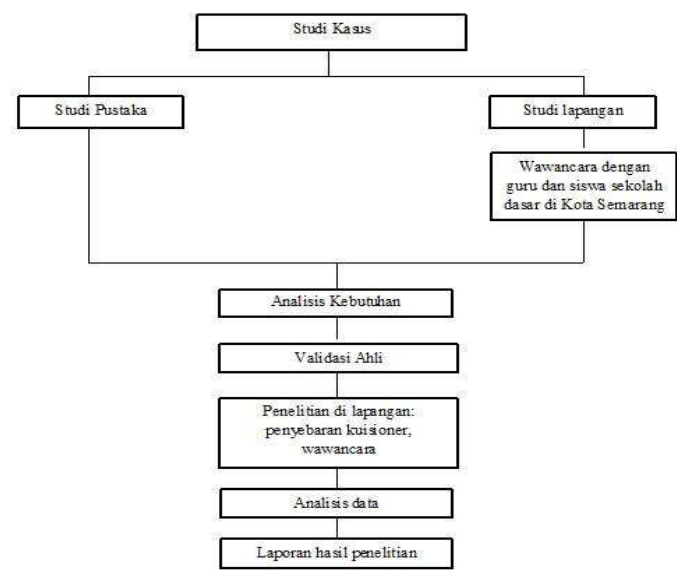

Gambar.1 Alur penelitian

Untuk analisis data secara kuantitatif dengan menggunakan analisis correlation product moment yaitu untuk mengetahui suatu ada atau tidak hubungan antar variabel, dan dapat dilihat proses hubungan antar variabel pada gambar 2 dibawah ini:

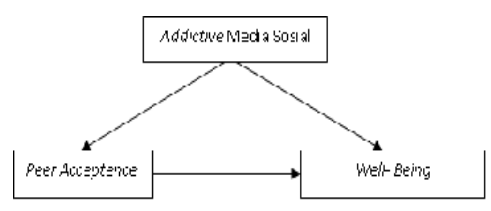

Gambar 2. Bagan hubungan antar variabel

Pada analisis kualitatif dilakukan dengan proses wawancara secara bergantian yaitu meliputi: alasan menggunakan gadget, akun media sosial apa saja yang mereka punya, berapa lama bermain media sosial dalam sehari, kenapa memakai media sosial itu, kegunanaan dan manfaat apa saja yang diperoleh dari memakai media sosial, dan perasaan apa saja yang dirasakan saat bermain media sosial dll sampai menemukan maknya hingga bisa ditarik kesimpulan.

\section{HASIL DAN PEMBAHASAN} diperoleh

Berdasarkan data subjek penelitian,

Tabel. 1 Data Subjek penelitian

\begin{tabular}{|c|c|}
\hline Jenis Kelamin & Jumlah \\
\hline Perempuan & 15 \\
\hline Laki-laki & 20 \\
\hline Total & $\mathbf{3 5}$ \\
\hline
\end{tabular}

Dari tabel diatas diperoleh jumlah siswa perempuan 15 dan 20 siswa laki-laki. Jika dilihat dari skor kategorisasi dari setiap variabel

Tabel 2. Skor kategorisasi

\begin{tabular}{|c|c|c|c|c|}
\hline Variabel & Median & \multicolumn{2}{|c|}{ Kategorisasi } & Total \\
\hline Well- & 211 & $\mathrm{X}>$ & Tinggi & 25 \\
being & & 211 & & \\
\cline { 3 - 5 } & & $\mathrm{X}<$ & Rendah & 10 \\
& & 210,5 & & \\
\hline $\begin{array}{c}\text { Addictive } \\
\text { media } \\
\text { sosial }\end{array}$ & 62 & $\mathrm{X}>62$ & Tinggi & 25 \\
\cline { 3 - 5 } & & $\mathrm{X}<$ & Rendah & 10 \\
& & 61,5 & & \\
\hline
\end{tabular}

Dari tabel kategori diatas diperoleh jumlah siswa yang kategori well-being tinggi berjumlah 20 siswa, dan yang well-being rendah berjumlah 10 siswa, sehingga dapat disimpulkan well being pada siswa SDN 1 Rejosari khususnya kelas 6 tergolong tinggi. Namun jika dilihat dari addictive media sosial pada siswa kelas 6 SDN 1 Rejosari tergolong tinggi, karena dibuktikan dengan jumlah total kategori tinggi berjumlah 25 siswa dan berdasarkan kategori rendah berjumlah 10 siswa. Dari analisis reliabilitas diperoleh:

Tabel 3. Hasil uji reabilitas

\begin{tabular}{|l|l|l|}
\hline \multicolumn{1}{|c|}{ Variabel } & \multicolumn{1}{|c|}{$\begin{array}{c}\text { Cronbach } \\
\text { Alpha }\end{array}$} & N of Items \\
\hline Well-Being &, 903 & 35 \\
\hline $\begin{array}{l}\text { Addictive } \\
\text { Media sosial }\end{array}$ &, 888 & 35 \\
\hline
\end{tabular}

Berdasarkan tabel diatas dapat disimpulkan bahwa data yang diperoleh reliabel.

Berdasarkan hasil analisis correlation product moment diperoleh: 


\section{Addictive Media Sosial dengan Well-Being}

Berdasarkan perhitungan uji hipotesis dengan menggunakan correlation product moment diperoleh nilai signifikansi $p=0,088(p$ $>0,05)$, maka tidak ada hubungan signifikan antara addictive media sosial dengan well-being karena $p$ lebih besar. Sedangkan hubungan keeratan antar addictive media sosial dengan well-being termasuk dalam hubungan negatif yaitu semakin siswa addictive media sosial maka well-beingnya semakin menurun, dan skor keeratan sebesar -0,205 maka termasuk hubungan lemah (Sujarweni, 2014).

Hal ini menyimpulkan bahwa tidak ada hubungan yang positif antara addictive media sosial dan well-being pada siswa sekolah dasar namun keeretan antar dua variabel negatif, yaitu semakin siswa sekolah dasar addictive media sosial maka well-beingnya semakin menurun. Hasil tersebut sesuai dengan penelitian yang dilakukan oleh Hou et al (2019) bahwa penelitian secara empirik tentang addictive media sosial berhubungan negatif dengan well-being. Penggunaan media sosial oleh siswa sekolah dasar pada era industri 4.0 memang sebuah keniscayaan namun bukan berarti harus meninggalkan media tradisional. Riset Oktavianti dan Ratnasari (2018) menunjukkan bahwa etnopedagogi sebagai pendekatan pembelajaran yang diimplementasikan melalui kegiatan pembelajaran yang menyajikan media berbasis kearifan lokal lebih efektif. Dalam penggunaan media berbasis keunggulan lokal seringkali diiringi dengan berbagai aktivitas bermain, sehingga menciptakan pembelajaran yang aktif, kreatif, efektif, dan menyenangkan. Hal ini menunjukkan bahwa etnopedagogi berhasil diaplikasikan pada pembelajaran di sekolah dasar jika pelaksanaan disajikan dengan kegiatan pembelajaran inovatif seperti media berbasis kearifan lokal.

Secara frekuensi penggunaan media sosial pada siswa sekolah sekolah dasar termasuk dalam kategori tinggi, namun secara hasil statistik tidak ada hubungan dengan well-being siswa sekolah dasar. Hasil wawancara sebagian besar siswa mengatakan bahwa menggunakan media sosial hanya sebagai bentuk eksistensi diri, berbagi informasi tentang diri sendiri, membicarakan hal-hal yang bersifat ringan, hanya untuk melihat-lihat informasi ataupun yang lain. Hal ini sesuai dengan hasil perhitungan secara statistika, mereka tidak merasa semakin tinggi well-beingnya karena menggunakan media sosial sudah seperti kebiasaan dan ketergantungan hanya scroll untuk melihat feed, melihat video, sebagai sarana menunjukan ekspresi seperti kebahagian, kekesalan maupun kesedihan bagi para informan dan memberitahu aktivitas yang sedang dilakukan.

Sebagaimana yang terjadi sekarang ini menurut Nazir (2008) bahwa perubahan sosial akan diikuti dengan dampak, baik dampak secara positif maupun secara negatif dan juga bisa berdampak pada yang akan terjadi. Hal tersebut juga diperkuat oleh Nursiti (2013) bahwa penggunaan media elektronik seperti komputer, notebook, handphone, juga menghancurkan secara perlahan terhadap kemampuan anak-anak maupun kalangan dewasa awal mereka akan berkurang intensitasnya dalam berinteraksi sehingga bisa menyebabkan anti sosial.

\section{Addictive Media Sosial, Peer Acceptence}

Berdasarkan perhitungan statistika dengan analisis korelasi product moment diperoleh $\mathrm{p}=$ 0,001 maka $\mathrm{p}<0,001$ sehingga dapat di simpulkan bahwa ada hubungan positif antara addictive media sosial dengan peer acceptence. Hasil penelitian tersebut juga didukung oleh penelitian yang dilakukan oleh Aldhayan et al (2019) bahwa penggunaan media sosial merupakan salah satu bentuk timbal balik untuk saling mengikuti, juga untuk membentuk sebuah grup.

Pada hasil wawancara juga hampir seluruh siswa mengatakan bahwa salah satu menggunakan media sosial karena teman-teman sebaya mempunyai beberapa akun media sosial, sehingga siswa yang belum punya cenderung terdorong untuk mempunyai akun tersebut. Ketika teman sebaya dalam kelas tersebut mengobrol, seringkali mereka saling bertukar cerita ataupun informasi yang mereka dapatkan dari menggunakan sosial media, saling menandai dalam sebuah foto di sosial media masingmasing, memamerkan segala aktivitas dan perasaan dalam media sosial. Mereka yang menggunakan mempunyai akun media sosial sering sekali membuat grup didalam kelas, dan yang tidak mempunyai media sosial tersebut mereka merasa terintimidasi. Hasil riset ini didukung dengan penelitian O'keefee et all (2011) menyatakan bahwa addictive penggunaan media sosial bagi anak sekolah dasar beresiko 
Alifia Cahya Wicaksani dan Ika Silfiana A. Khoiriyah

STUDI KASUS: ADDICTIVE MEDIA SOSIAL, PEER ACCEPTENCE DAN WELL-BEING ...

REFLEKSI EDUKATIKA : Jurnal Ilmiah Kependidikan, Volume 10, Nomor 2, Juni 2020, hlm. 138-143

mengandalkan pertemanan sebaya, konten yang tepat, kurangnya privasi, adanya influecer. Di sisi lain, berdasarkan penelitian Pratiwi, Ardianti, dan Kanzunnudin (2018) maka yang dibutuhkan siswa sekolah dasar yaitu adanya kegiatan pembelajaran secara berkelompok sehingga memunculkan kemampuan bekerjasama pada masing-masing siswa yang berbeda dengan dirinya.

\section{Peer Acceptence dan Well-Being}

Hasil uji statistik dengan menggunakan analisis correlation product moment menunjukan nilai $\mathrm{p}=0,002$ maka $\mathrm{p}<0,002$ sehingga dapat disimpulkan bahwa adanya hubungan positif antara peer acceptence dan well-being. Penelitian yang dilakukan oleh Kuo dan Liu (2008) menyatakan bahwa hubungan interpersonal mempengaruhi kecanduan internet, yaitu dengan mereka tidak puas hubungan sosial pertemanan mereka semakin kecanduan.

Dari pembahasan juga dibuktikan dari hasil wawancara terhadap siswa kelas 6 di SDN Rejosari 1 Semarang. Sebagian besar menyatakan bahwa mereka merasakan wellbeingnya tinggi ketika mereka bisa bersamasama seperti saling tukar cerita baik pengalaman, aktivitas, informasi maupun kejadian-kejadian yang dialami. Ketika mereka bisa saling berbagi informasi membuat mereka merasa aman karena berada dalam lingkungan teman-teman sebayanya. Nasution dan Evrika (2007) bahwa remaja awal baik perempuan maupun laki-laki lebih sering menghabiskan waktu dengan temanteman sebayanya dari pada dengan orang tua sendiri.

\section{SIMPULAN}

Berdasarkan hasil penelitian dapat disimpulkan bahwa addictive media sosial dengan well-being tidak terdapat hubungan yang positif, namun berhubungan secara negatif yaitu semakin siswa addictive maka well-beingnya semakin menurun, sedangkan addictive media sosial berhubungan positif terhadap peer acceptence siswa sekolah dasar dan peer acceptence juga memberikan hubungan yang positif terhadap well-being siswa.

\section{DAFTAR PUSTAKA}

Aldhayan, Manal., Cham, Sainabou et.all. 2019. Online Peer Support Groups to Combat Digital Addiction: User Acceptance and Rejection Factors. WorldCIST'19 AISC, 139-150.

Andreassen, C.S., Griffiths, M.D., Gjertsen, S.R., Krossbakken, E., Kvam, S., \& Pallesen, S 2013. The relationship between behavioral addictions and the five factor model of personality. Journal of Behavioral Addictions, 2: 90-99.

Andreassen, Cecile Schou, Pallesen, Stale, Griffiths, Mark D. 2017. The relationship between addictive use of social media, narcissism, and selfesteem: Findings from a large national survey. Addictive behavior. 64: 287-293.

Creswell, John W. 2016. Penelitian Kualitatif \& Desain Riset. Yogyakarta: Pustaka Pelajar

D. Karaisko, E. Tzavellas, G. Balta, T. Paparrigopoulos. 2010. Social Network Addiction: a new clinical disorder?. European Psychiartry. 25 (1): 855.

Ervika, E., \& Nasution, A.S.M. 2007. Hubungan Penerimaan Sebaya dengan Perasaan Kesepian pada Remaja. Psikologika, 3 (2): 72-77.

Hou, Yubo., Xiong, Dan., Jiang, Tonglin et.all. 2019. Social Media Addiction: Its Impact, Mediation, and Intervention. Journal of Psychosocial Research on Cyberspace, 13 (1).

Kominfo. 2018. Data statistik penggunaan media sosiak $=l$ di kalangan anak-anak dan remaja. https://www.kominfo.go.id

Liu, Chia Yi dan Kuo, Feng Yang. 2008. A Study of Internet Addiction through the Lens of the Interpersonal Theory. Cyberpsychology \& Behavior. 10 (6).

Mary E, Gifford Smith dkk. 2003. Chilhood Peer Reliationships: Social Acceptance, 
Alifia Cahya Wicaksani dan Ika Silfiana A. Khoiriyah

STUDI KASUS: ADDICTIVE MEDIA SOSIAL, PEER ACCEPTENCE DAN WELL-BEING ...

REFLEKSI EDUKATIKA : Jurnal Ilmiah Kependidikan, Volume 10, Nomor 2, Juni 2020, hlm. 138-143

Friendship and Peer Networks. Journal Of School Psychology, 41: 235-284.

Nazsir, R.N. 2008. Sosiologi Kajian Lengkap Konsep dan Teori Sosiologi sebagai Ilmu Sosial. Bandung: Widya Padjajaran.

Oktavianti, Ika dan Ratnasari, Yuni. 2018. Etnopedagogi Dalam Pembelajaran Di Sekolah Dasar Melalui Media Berbasis Kearifan Lokal. Refleksi Edukatika : Jurnal Ilmiah Kependidikan, 8 (2): 149154.

O'Keefee, Gwenn Schurgin., Pearson, Kathleen Clarke. 2011. The Impact of Social Media on Children, Adolescents, and families. Pediatrics, 127: 800.

Pratiwi, Ika Ari., Ardianti, Sekar Dwi., dan Kanzunnudin, Moh. 2018. Peningkatan Kemampuan Kerjasama Melalui Model Project Based Learning (PJBL) Berbantuan Metode Edutainment Pada Mata Pelajaran Ilmu Pengetahuan Sosial.
Refleksi Edukatika : Jurnal Ilmiah Kependidikan, 8 (2): 177-182.

Peerin, Andrew. 2015. Social Media Usage: 2005-2015 65\% of adults now use social net working sites- a nearly tenfold jump in the past decade. Pew Research Center.

Rice, F. P; \& Dolgin, K. G. 2002. The Adolescent: Development, Relationship and The Culture, 10th edition. USA: Allyn \& Bacon Company.

Settani, Michelle, Azucar, Danny et al. 2018. Predicting Individual Characteristics from Digital Traces on Social Media: A MetaAnalysis. Cyberpsychology, Behavior, and Social Networking, 21(4).

Sujarweni, Wiratna.V. 2014. SPSS untuk Penelitian. Yogyakarta: Pustaka Baru Press.

WeAreSocial. 2016. https://wearesocial.com/specialreports/digital-in-apac-2016 